\title{
ДЕНЬ ПАМЯТИ 5. БОРИС ПЕТРОВИЧ ДИТМАР У ОСНОВ ВУЗОВСКОЙ ГЕОГРАФИИ В ВОРОНЕЖЕ
}

\author{
В.И. Шмыков \\ Воронежский государственный педагогический университет, Россия \\ Поступила в редакияию 28 декабря 2018 г.
}

\begin{abstract}
Аннотация: В статье дается обзор основных этапов жизни и деятельности профессора Б. П. Дитмара, заложившего основы высшего географического образования в г. Воронеж. Проанализированы профессиональные особенности педагогического стиля как педагога, ученого и руководителя первых кафедр физической географии в ВГПУ и ВГУ, и его вклад в становлении подготовки физикогеографов.
\end{abstract}

Ключевые слова: Б. П. Дитмар, кафедра, университет, география.

Abstract: The article provides an overview of the main stages of the life and work of Professor B.P. Ditmar, who laid the foundations of higher geographical education in the city of Voronezh. The professional features of the pedagogical style as a teacher, scientist and head of the first departments of physical geography in the Voronezh State Pedagogical University and Voronezh State University, and its contribution to the development of training of physical geographers are analyzed.

Key words: B. P. Dietmar, department, university, geography.

Борис Петрович Дитмар был первым профессиональным географом, который стоял у основ подготовки учителей географии в городе Воронеже. Становление его как гражданина, ученого, преподавателя важно для понимания этой важной миссии.

Происходил он из немецкого дворянского рода, укоренившегося на небольшом острове Эзель (Сааремаа в Эстонии) в Балтийском море: когда-то сюда в ходе немецкой колонизации Прибалтики пришли его представители. Позже эта территория вошла в состав России и стала называться Лифляндской губернией. Род Эзельских фон Дитмаров дал России военных и ученых, юристов и предпринимателей. Родился Б. П. Дитмар 04.02.1878 года в Москве, где прошли его детские и отроческие годы. Получил хорошее образование, поступил на естественное отделение физико-математического факультета Императорского Московского университета (МГУ). Специализировался по физической географии у профессора Д.Н. Анучина, проявил себя в научно-исследовательской деятельности, занимаясь полевыми исследованиями рек Покровского уезда Владимирс-

() Шмыков В.И., 2019 кой губернии. Интересен факт, что, будучи студентом, перевел монографию о Франции с французского языка для издательства [2]. Эта книга хранится как в фондах ВГПУ, так и ВГУ. В 1905 году он по плану научно-исследовательской работы кафедры изучал и описал карстовую реку Пониклю в Смоленской губернии. Закончив обучение в МГУ в 1906 году, далее до 1918 года преподавал географию в гимназиях, реальных училищах города Москвы. В летние месяцы работал в экспедициях. В 1908 году принимал участие в Мурманской экспедиции Гидрографического отдела Морского министерства. В 1914-1915 годах работал в Олонецкой экспедиции по исследованию озер Петрозаводского и Повенецкого уездов. За научные результаты в Олонецкой экспедиции Борис Петрович был награжден малой золотой медалью Русского Императорского Географического общества.

В 1919 году Б.П. Дитмар переключается на педагогическую работу в высших учебных заведениях: в 1919-1920 годах он состоит профессором метеорологии Тверского института народного образования. Документально установлено, что Б. П. Дитмар в 1922 году находился в штате кафедры географии 1-го МГУ в должности приват-до- 
цента [6]. Из данной монографии не ясно, какие курсы вел Борис Петрович, но отмечено, что при формировании библиотеки Географического музея в 1922 году приняли участие преподаватели кафедры географии, в том числе упомянута фамилия Б. П. Дитмара. В монографии Ю.Г. Симонова об истории Географического факультета МГУ конкретно выделено, что в 1925-1926 годах от Б. П. Дитмара поступило 160 томов научной литературы из общего количества поступивших 298 томов [6]. В 1928 году Борис Петрович совместно с профессором МГУ М.С. Боднарским опубликовали «Краткий курс географии СССР». Далее там же приводится план кафедры на первую советскую пятилетку, где Б. П. Дитмаром запланирована научно-исследовательская работа в НИИ Географии МГУ на 5 лет «Изучение озер Среднего и Южного Урала» [6].

В 1930-1934 годах Борис Петрович читает курс физической географии СССР в Московском гидрометеорологическом институте.

В 1934 году он был приглашен в Воронежский государственный педагогический институт (ВГПИ) на должность только что созданной кафедры физической географии. Здесь проявился весь его опыт, приобретенный на кафедре географии МГУ, работая в школе, в экспедициях. Но в должности заведующего кафедрой он показал себя и как квалифицированный организатор, и как руководитель, что отмечал в своих воспоминаниях его первый ученик М. А. Зубащенко. На плечи заведующего кафедрой легли заботы по составлению учебного плана, подбору преподавателей, приобретению литературы, настенных карт, атласов и другого оборудования. Имея большие связи с книготоргующими и букинистическими организациями, он сумел собрать приличную библиотеку, содержащую всю основную, а также и редкую, эксклюзивную, географическую литературу, в том числе на иностранных языках. Были собраны почти все необходимые атласы, как отечественных издательств, так и некоторых зарубежных. Создан большой фонд карт, таблиц, картин, стереоскопических открыток с видами природы. Под руководством Б. П. Дитмара была организована работа по разработке, составлению и изготовлению оригинальных учебных пособий студентами и сотрудниками кафедры.

Борис Петрович преподавал курсы по циклу общего землеведения и региональной физической географии. Он сразу стал признанным лидером на факультете. Высокая общая культура, географическая эрудированность, замечательные лекторские качества, организаторские способности, увлечен- ность делом сделали Б. П. Дитмара непререкаемым авторитетом на географическом факультете. В 1935 году без защиты диссертации ему была присвоена степень кандидата географических наук и ученое звание профессор.

В 1935 году была открыта аспирантура на кафедре физической географии, Б. П. Дитмар стал ее первым руководителем. Его аспирантами в пединституте были М.А. Зубащенко, Л.С. Осокин, А. Н. Овчаренко. Первые из его учеников в дальнейшем сами стали организаторами науки, руководителями подразделений и служб ВГПИ. Так, М. А. Зубащенко в 1939 году стал заведующим кафедрой физической географии, а Л.С. Осокин преподавателем кафедры. Позже, в 1945 году, Л. С. Осокин был приглашен Б.П. Дитмаром на кафедру физической географии Ярославского пединститута. Там он защитил кандидатскую диссертацию и читал курсы географии почв и общего землеведения, занимал должность декана факультета иностранных языков [5].

В 1935 году Б. П. Дитмар был приглашен по совместительству на должность заведующего созданной впервые кафедры физической географии в Воронежском государственном университете [4]. А студенты ВГПИ слушали лекции не только своих штатных преподавателей института, но и ведущих педагогов ВГУ - Н. С. Камышева, Г. Н. Лиодта и других. Кроме того, приглашались для чтения отдельных курсов профессора московских вузов, в основном знакомые Б. П. Дитмара по работе в МГУ - профессора С. В. Чефранов, М. С. Боднарский, В. В. Богданов.

С именем Б. П. Дитмара связано и издание первого номера Известий Воронежского Государственного педагогического института, где он был ответственным редактором [3]. В научном сборнике впервые были опубликованы результаты полевых исследований по геоморфологии Воронежской области.

Заслуги Б. П. Дитмара в становлении географического образования в Воронеже просто огромны. Его видение географии и огромный опыт полевых исследований заложили крепкий фундамент географической подготовки, как студентов, так и преподавательского состава географических факультетов ВГУ и ВГПИ. Геоморфологическое направление исследований территории Воронежской области и Центрального Черноземья, начатое Б. П. Дитмаром, на долгие годы стало основным для многих поколений географов, выпускников ВГПИ.

В 1939 году Б. П. Дитмар был вынужден сменить место работы и перейти в Крымский педин- 
ститут, где работал до оккупации в 1942 году. Перед оккупацией Крымский пединститут был эвакуирован в город Махачкалу, где объединился с Дагестанским пединститутом. В сентябре 1943 года проф. Б. П. Дитмар был приглашен на должность заведующего кафедрой физической географии Ярославского педагогического института, где и работал до конца своей жизни (24.09.1948). Его товарищ по МГУ, профессор М.С. Боднарский, характеризовал Дитмара как прекрасного семьянина, доброжелательного и отзывчивого товарища и сослуживца, гостеприимного хозяина, интересного и приятного собеседника [1]. Важно, что дело отца продолжил его сын, Андрей Борисович, известный ученый, доктор географических наук, профессор, видный историк географии [5].

Где бы не работал Борис Петрович Дитмар, о нем осталась память, как об ученом, преданном любимой науке Географии и учительскому служению.

\section{Основные труды Б. П. Дитмара}

1. Курс географии России : учебник для гимназии. - Москва, 1911.

2. Курс общей географии, составленный для $\mathrm{V}$ кл. мужских гимназий по новым программам М.Н.П. / Б. Дитмар, Е. Степаненко. - Москва : тип. т/д И.С. Коломиец и К ${ }^{\circ} 1915 .-209$ с.

3. Краткий учебник географии России : с приложением очерка окраинных государств : с 5 схематическими картами в тексте / Б. Дитмар ; [авт. предисл. М. М. Боднарский]. - 2-е изд. перераб. под ред. М. С. Боднарского. - Москва : Государственное издательство, 1922. - 132 с.

4. Краткий учебник географии СССР / Б. П. Дитмар, М. С. Боднарский. - 3-е изд. - Москва-Петроград, 1923.

5. Краткий учебник географии С.C.C.P : С прил. очерка западных окраинных государств / Б. Дитмар, М. Боднарский. - 3-е изд. - Москва; Петроград : Государственное издательство, 1924. - 140 с.

6. Трактаты о двух Сарматиях Матвея Меховского. // Землеведение. - Москва, 1928. - Т. XXX, вып. IV.

7. География Эратосфена // Землеведение. Москва, 1929. - Т. XXXI, вып. IV.

8. Геоморфологические районы Воронежской и Тамбовской областей / Б. П. Дитмар, И. К. Сысоев // Известия Воронежского государственного педагогического института. - 1938. - Т. ІІІ, вып. 2. - C. 19-26.

Шмыков Виктор Ильич

кандидат географических наук, доцент кафедры географии и туризма Воронежского государственного педагогического университета, г. Воронеж, E-mail: shmykov1949@mail.ru
9. Геоморфологические наблюдения в районе Доно-Ведуго-Девицкого водораздела / Б. П. Дитмар, В. К. Золотарева // Известия Воронежского государственного педагогического института. 1939. - T. VI, вып. 2. - С. 17-22.

10. Очерки физической географии (Америка, Африка, Австралия): Конспект лекций для высшего учебного заведения. - Воронеж, 1938. (Рукопись (3 п.л.).

\section{СПИСОК ЛИТЕРАТУРЫ}

1. Боднарский М. С. Б. П. Дитмар / М. С. Боднарский // Известия ВГО. - 1949. - № 3. - С. 345.

2. Генен Е. Новая Франция / Е. Генен; пер. с фр. Б. П. фон Дитмара. - Москва : Типо-литография А. П. Поплавского, 1901. - 663 с. - (Премировано Французской Академией).

3. Известия Воронежского Государственного педагогического института / ред. кол. Б. П. Дитмар, Л. С. Хренов. - 1936. - Т. 1.

4. Карпачев М. Д. Воронежский университет; вехи истории. 1918-2013 / М. Д. Карпачев. - Воронеж : Издательство Воронежского государственного университета, 2013. $-560 \mathrm{c}$.

5. Рохмистров В. Л. А. Б. Дитмар - ученый, педагог, человек / В. Л. Рохмистров, В. А. Щенев // Ярославский педагогический вестник. Сер. Гуманитарные науки. - 2008. - № 4(57). - С. 252-256.

6. Симонов Ю. Г. История географии в Московском университете: события и люди / Ю. Г. Симонов. Москва : Городец, 2008. - Т. 1. - 504 с.

\section{REFERENCES}

1. Bodnarskiy M. S. B. P. Ditmar / M. S. Bodnarskiy // Izvestiya VGO. - 1949. - № 3. - S. 345.

2. Genen E. Novaya Frantsiya / E. Genen; per. s fr. B. P. fon Ditmara. - Moskva : Tipo-litografiya A. P. Poplavskogo, 1901. - 663 s. - (Premirovano Frantsuzskoy Akademiyey).

3. Izvestiya Voronezhskogo Gosudarstvennogo pedagogicheskogo instituta / red. kol. B. P. Ditmar, L. S. KHrenov. - 1936. - T. 1.

4. Karpachev M. D. Voronezhskiy universitet; vekhi istorii. 1918-2013 / M. D. Karpachev. - Voronezh : Izdatel'stvo Voronezhskogo gosudarstvennogo universiteta, 2013. - $560 \mathrm{~s}$.

5. Rokhmistrov V. L. A. B. Ditmar - uchenyy, pedagog, chelovek / V. L. Rokhmistrov, V. A. SHCHenev //YAroslavskiy pedagogicheskiy vestnik. Ser. Gumanitarnyye nauki. - 2008. - № 4(57). - S. 252-256.

6. Simonov YU. G. Istoriya geografii v Moskovskom universitete: sobytiya i lyudi / YU. G. Simonov. - Moskva : Gorodets, 2008. - T. 1. - 504 s.

Shmykov Victor Il'itch

Candidate of Geographical Sciences, Associate Professor of the Department of geography and tourism, Voronezh State Pedagogical University, Voronezh, E-mail: shmykov1949@mail.ru 